\title{
Mediating role of need satisfaction on total reward management towards retention: a conceptual framework
}

\author{
Jeeta Sarkar, Lalatendu Kesari Jena and Kalpana Sahoo \\ School of Human Resource Management, XIM University Bhubaneswar, \\ Bhubaneswar, India
}

Mediating role of need satisfaction

Received 23 March 2021

Revised 14 June 2021 22 July 2021

3 September 2021

Accepted 4 September 2021

\begin{abstract}
Purpose - This paper aims to investigate the impact of total rewards on retention. The finding relies on need satisfaction approach as a mechanism. This is done by investigating the role of need satisfaction of "autonomy, competence and relatedness" as possible mediators between elements of total rewards and retention.

Design/methodology/approach - This paper focussed on exploring the literature published in various popular databases .Based on the conceptual analysis, a set of possible frameworks linking the three constructs has been stated for future research.

Findings - The research has evolved with few possible frameworks to model the assertions by investigating and corroborating it with quantitative studies to be empirically tested.

Originality/value - The originality lies in applying self-determination theory framework of need satisfaction mechanism in explaining the relationships between total rewards and retention, thereby adding new insights to the employee retention literature.
\end{abstract}

Keywords Retention, Self-determination theory, Total rewards, Need satisfaction

Paper type Conceptual paper

\section{Introduction}

Why do some industries experience lower voluntary employee turnover as compared to ones with highest even after implementing total rewards program? Is it not taking into account changing needs and requirements of the employees? Employees are biggest differentiators for attaining sustainable competitive advantage (Taamneh et al., 2018) and rewarding them is the biggest investment (Bryant and Allen, 2013). Thus, rewarding them goes beyond paying salaries for stimulating performance and achieving organizational results. For example, the total rewards preference model highlights the importance of employees' preferences having a positive influence on attracting, motivating and retaining key employees (Close and Martins, 2015). Over the period of 20-25 years, vast research has

(c) Jeeta Sarkar, Lalatendu Kesari Jena and Kalpana Sahoo. Published in Vilakshan - XIMB Journal of Management. Published by Emerald Publishing Limited. This article is published under the Creative Commons Attribution (CC BY 4.0) licence. Anyone may reproduce, distribute, translate and create derivative works of this article (for both commercial and non-commercial purposes), subject to full attribution to the original publication and authors. The full terms of this licence maybe seen at http:// creativecommons.org/licences/by/4.0/legalcode

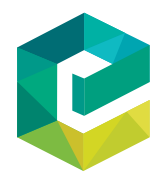

Vilakshan - XIMB Journal of Management Emerald Publishing Limited 0973-1954 DOI 10.1108/XJM-03-2021-0083 
hinted towards the fact that total rewards - the sum of all kind of financial and non-financial rewards - is a critical lever in achieving higher retention (Alhmoud and Rjoub, 2020).

Still there exists limited information on need satisfaction approach of total rewards which is instrumental in driving positive workplace outcomes (Thibault Landry and Whillans, 2018). This happens because these organizations view employees as a single group with homogenous needs while proactive organisations always ensure in considering an employee's requirements before offering them the benefits (Silverman and Reilly, 2003). The current study relies on selfdetermination theory's (SDT) conceptualization of psychological needs which is dominated by the studies saying that satisfaction of these needs leads to positive workplace outcomes such as job commitment, satisfaction, engagement and lower turnover (Haivas et al., 2014; Bharath and Sreedevi, 2021). The study seeks to use SDT perspective to study employee retention as a function of total rewards through need satisfaction.

\section{Methodology: identifying relevant studies}

The authors carried out an extensive review of total rewards related studies using databases, namely, Google Scholar, EBSCO, Proquest ABI, JSTOR, Emerald and Sage. The scholarly articles were searched using keywords such as "total rewards and retention"; "total rewards and need satisfaction"; "the relationship between total rewards and retention"; "need satisfaction and employee retention"; "linkage between total rewards and retention"; "the effect of need satisfaction on employee retention." Initially articles were thoroughly read and analysed looking at their keywords, titles and abstracts. There were instances where the full articles were read so as to determine the type of the study. It was found that research work (Table 1) on rewards has been evident since 1983 and on total rewards on since 1999, and since then research on total rewards has witnessed substantial change. Hence, articles from the year 1983 to 2021 have been considered for review in this paper. Finally, a total of 90 articles were shortlisted. Studies were segregated as per theoretical-based literature consisting of empirical studies having theoretical underpinnings and atheoretical studies consisting of field studies, conceptual articles and exploratory surveys.

For the purpose of systematically reviewing the literature and developing a conceptual framework, we have considered theory-based studies. The process enhances our understanding on theoretical perspectives of total rewards construct along with its association with workplace outcomes.

\section{Review of literature}

\section{Total rewards}

Recent years have seen a rise in scholarly and practitioners' works pertaining to embracing total rewards - a holistic approach of rewarding an employee in all the possible manner that

\begin{tabular}{llr}
\hline Type of study & Sub-type & $\begin{array}{c}\text { No. of } \\
\text { articles }\end{array}$ \\
\hline Theory based literature & Empirical & 43 \\
& Conceptual (Qualitative reviewing of literature with theoretical base) & 6 \\
Atheoretical studies & Field studies & 7 \\
& Exploratory surveys & 6 \\
& Conceptual articles (Practitioner's prescription/reports on & 24
\end{tabular}

Table 1.
Articles segregated according to the type of the study
Source: Authors' own 
an employee value in his employment relationship with the organization (Prouska et al., 2016). The transformational journey from compensation to total rewards has been well captured by Jiang et al. (2009) when he stated that "[w]hat once was 'compensation', or 'total compensation' has evolved into an interdependent triad of total rewards." Total rewards represent an organization's strategy of rewarding employees by integrating different components or practices such as learning and development with high-quality work life along with packages of competitive compensation and benefits (Nienaber et al., 2011).

\section{Theory-based literature}

The theory-based review of total rewards is diverse, embracing conceptual and empirical scholarly works with varied theoretical perspectives and empirical findings. Table 2 displays the studies with their theoretical orientation, central hypotheses of the theories, variables included along with their empirical findings.

Of the selected articles, 38 articles have focused on different theories to explore different perspectives and associations of total rewards with consequences (workplace outcomes). These articles have used 16 different theories directly addressing rewards and workplace outcomes. Theory-based studies on total rewards have had been mostly empirical (Twenge et al., 2010; Mabaso and Dlamini, 2021) with very few conceptual studies (Martin and Ottemann, 2016). The survey of these studies suggests that total rewards owe its theoretical roots to theories of motivation, namely, Maslow theory (Mulvey et al., 2000); equity theory (Rai et al., 2019); expectancy theory (Martin and Ottemann, 2016); and Herzberg's two-factor theory (Mabaso and Dlamini, 2021). Dominant theories of motivation revolved around a central hypothesis - employees' attitude towards total rewards, behaviour and performance are a function of personal expectancies, fulfilment of needs and perceived fairness of receiving the rewards. Table 2 details the findings of individual studies relying on different theories to develop framework and empirically testing the associations between total rewards and organizational outcomes.

\section{Theoretical results and research gaps}

Few observations that paved the way for identifying research gaps while analysing the literature are discussed below.

\section{Lack of focus on basic psychological need satisfaction}

In spite of owing its evolution to theories of motivation, actual empirical works have ignored the relationship between total rewards and satisfaction of basic psychological needs except a few (Thibault Landry and Whillans, 2018). Ryan and Deci (2017) opined that in spite of enormous amount of research taking place on compensation and rewards, a very few of them have considered its relationship with need satisfaction of employees and its mediation between rewards and workplace positive outcomes.

\section{Redundancy of social exchange theory (SET) theory}

As compared to SET (Cropanzano and Mitchell, 2005), SDT is more non-obligatory, more consensual and suited to the interests of organizational management (Gagné and Deci, 2005). Further, in a series of studies conducted by Rosen et al. (2014), SET is found to be redundant having lesser utility in predicting outcomes with SDT in a sense that "socio-emotional or personal resources exchanged" led to need satisfaction and predicted SET associated outcomes. Lian et al. (2012), in their study, used three competing theories, namely, SDT, SET and justice alternatively to better understand the relation between abusive supervision and
Mediating role of need satisfaction 
XIMB

Table 2.

Theory based literature

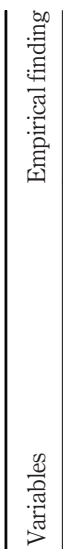

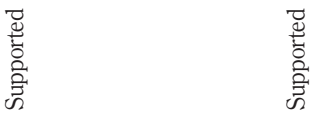

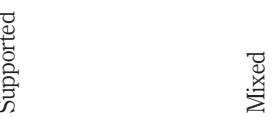

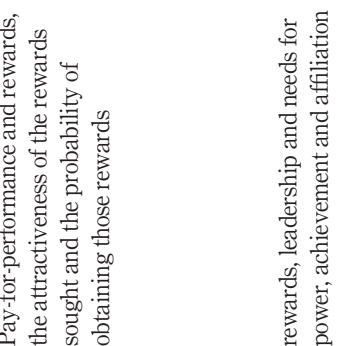

는

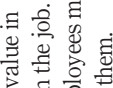

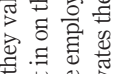

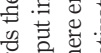

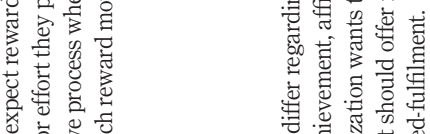

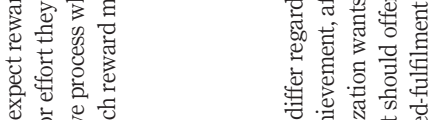

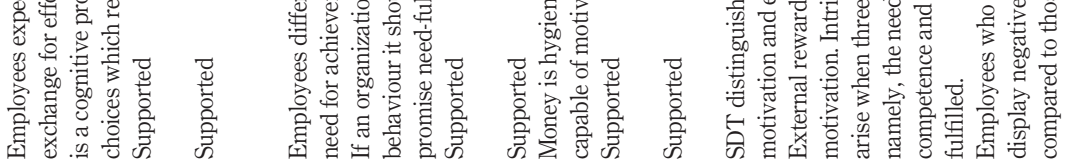

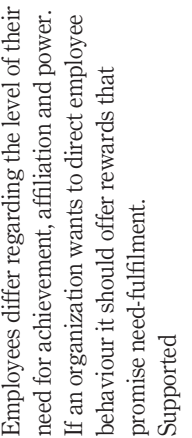

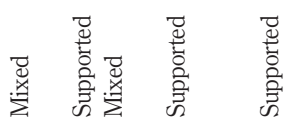

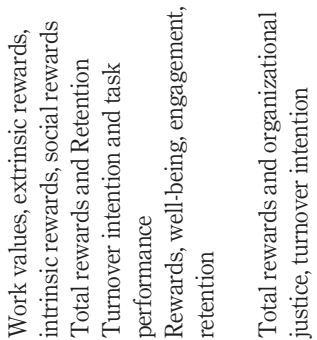

高

然

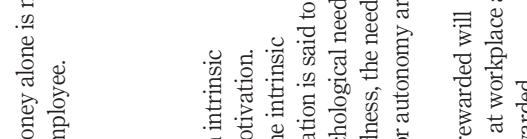

害势

薄

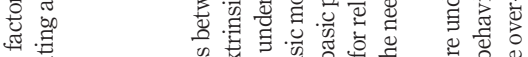
可

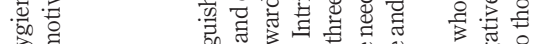

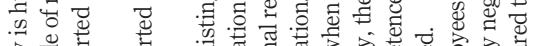

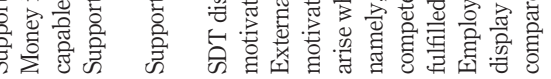

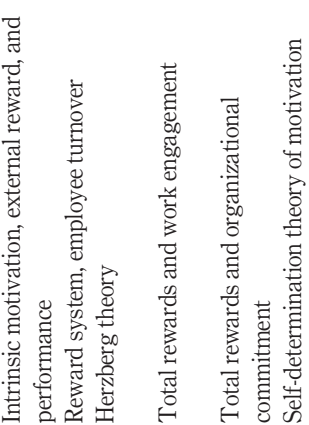
害

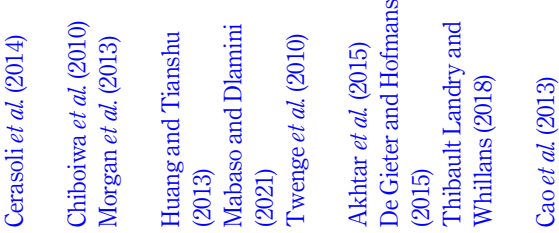
เ

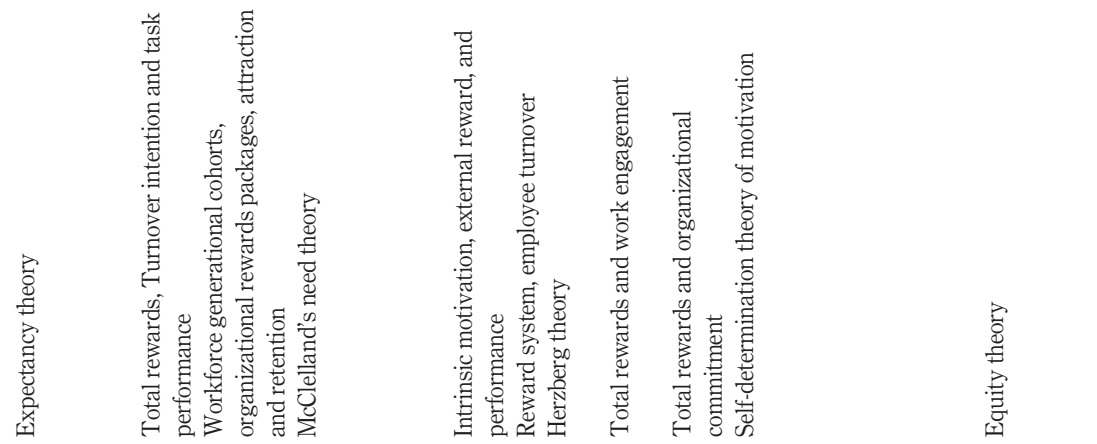

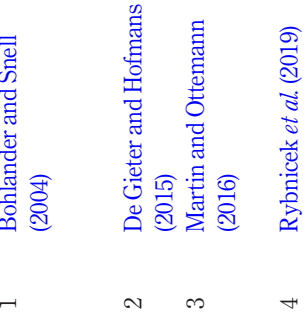




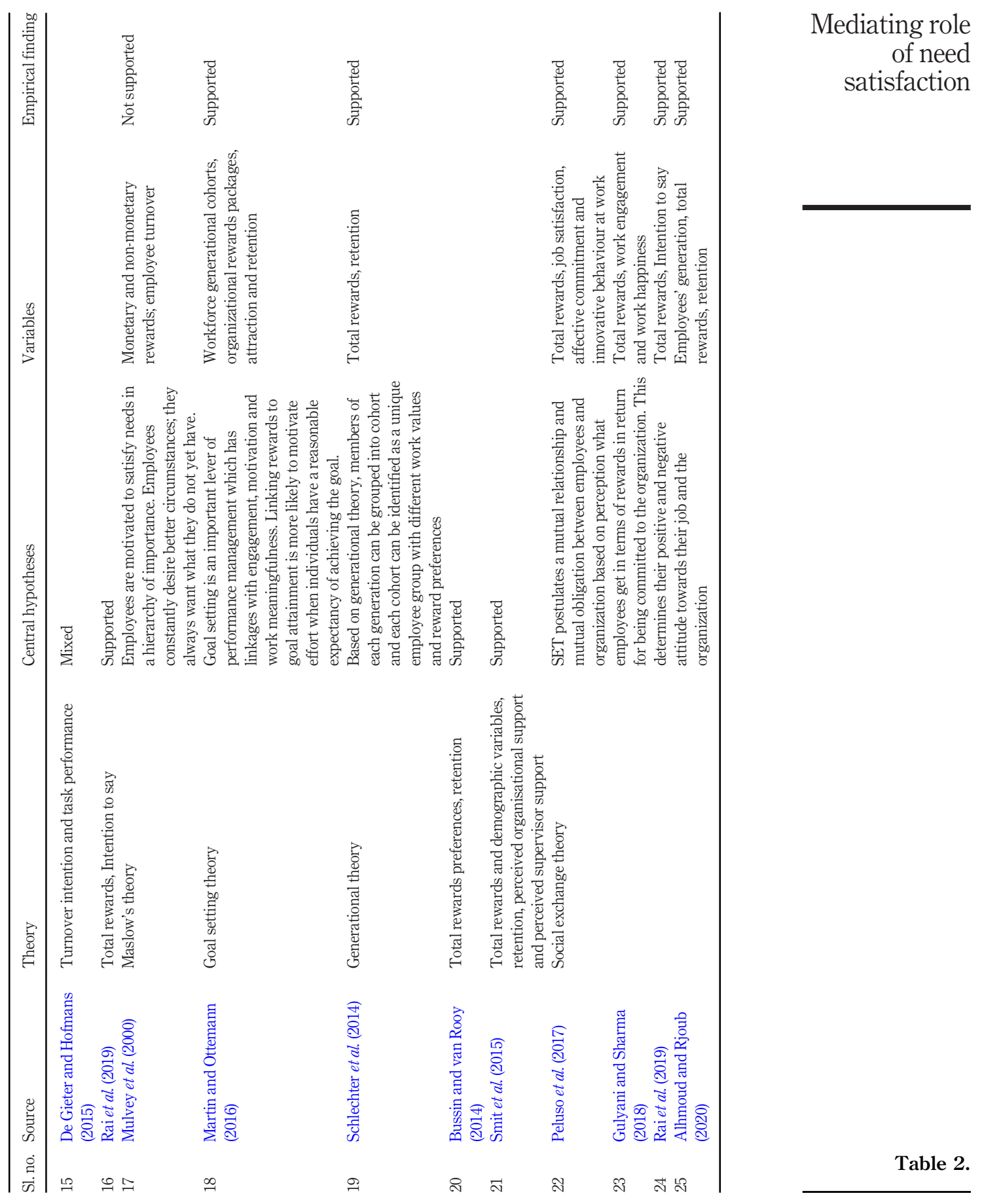


organizational deviance. The results showed that abusive supervision had a stronger effect (through basic need satisfaction) on organizational deviance and that of SET and justice were not significant.

\section{Basic psychological need subdued in total rewards}

Most of the articles have ignored the impact of basic needs satisfaction on retention. Other studies treated basic needs satisfaction to be inherent in total rewards in terms of choice and rewards preferences (Fobian and Maloa, 2020) rather than treating needs satisfaction as a predictor of positive workplace outcomes. A handful of recent studies have considered needs satisfaction as an antecedent of retention (Rathi and Lee, 2017).

\section{Shift towards non-motivational theories}

Recently, total rewards studies based on generational theory, Herzberg's' theory and SET shifted the focus towards a transactional and obligatory strategy of mutual give and take depending on your demographic patterns (Gulyani and Sharma, 2018; Alhmoud and Rjoub, 2020).

\section{Dearth of research in collectivistic country like India}

A study in Indian work setup may offer understanding into differences in employee needs satisfaction and expectations of employees to continue working for an organization. Literature on need satisfaction approach to rewards - retention relationships - is very limited (Rathi and Lee, 2017).

\section{Development of conceptual model}

Studies have affirmed that total rewards are the best strategy to attract, engage and retain workforce (Alhmoud and Rjoub, 2020). Hill and Tande (2006) have highlighted that " $88 \%$ of highly skilled employees leave the organizations for reasons that are not based on money, but the main reasons were limited development opportunities (39\%), unhappiness with management (23\%), lack of recognition $(17 \%)$ and other reasons $(10 \%)$." Based on these academic instances, it is proposed that:

\section{P1. Total rewards is positively associated with retention.}

Limited research is found on exploring the impact of total rewards on basic psychological need satisfaction. Ryan and Deci (2017) rightly pointed out "although there has been an enormous amount of research on rewards in organizations, very little of it has considered the relation of pay to basic psychological need satisfaction of employees which mediated between rewards and critical positive outcomes." Similar arguments were put forward by Deci et al. (2017). The relation between total rewards and SDT's need satisfaction is based on the assumption that components of total rewards have two aspects, namely, informational and controlling aspects (Ryan and Deci, 2017). The theorized relationships between tangible rewards and need satisfaction were as follows: tangible reward is designed to be salient in controlling aspect thereby reducing the feelings of autonomy (Deci et al., 1999); intangible reward is salient in informational aspect, i.e. it provides information on performance and development opportunities, thereby satisfying individuals' need for competence (Vansteenkiste and Deci, 2003); and the processes through which the tangible reward is administered may be or may not be related to need for relatedness. Therefore, one would expect that both tangible and intangible rewards are related to need satisfaction autonomy, competence and relatedness (Baard et al., 2004; Deci and Rayn, 2001). Owing to very scarce 
or no empirical evidence but with theoretical underpinning, the authors propose the following:

P2. Total rewards is positively associated with need satisfaction for autonomy, competence and relatedness.

There have been few studies with findings indicating that the need satisfaction for "autonomy, competence and relatedness" enhance intention to stay because satisfaction of needs will lead to employees becoming more committed towards the organization and hence developing tendency to remain with the organisation (Greguras and Diefendorff, 2009; Haivas et al., 2014). There are few evidences highlighting the influential role of needs satisfaction of the need for autonomy and competence on retention. For example, Rathi and Lee (2017) stressed on a same reason that employees experiencing autonomy and competence are more unlikely to sacrifice and leave their present job because of organizational fit experienced by the employees. With respect to need satisfaction for relatedness, previous studies have found that high-quality relationships at work are important for employee retention (Rathi and Lee, 2017). The above-mentioned studies provide the ground for the following proposition.

P3. Need satisfaction for autonomy, need satisfaction for competence and need satisfaction for relatedness are positively related with retention.

Academic literature instances are limited. Tiwari and Garg (2019) and Gözükara and Şimşek (2015) have used need satisfaction as a mediator with respect to job performance leadership, work engagement, job satisfaction and commitment. A recent study by Steindórsdóttir et al. (2020) used need satisfaction as a mediator between perceived masery climate and retention. A handful of studies have considered needs satisfaction as a potential mediator between pay and retention (Olafsen et al., 2015). Therefore, it is proposed that total rewards facilitating basic psychological need satisfaction will result in greater retention.

P4. Need satisfaction for autonomy, need satisfaction for competence and need satisfaction for relatedness mediate the relation between total rewards with retention.

Combining all the propositions, the proposed research model explaining the causality between the constructs is depicted in Figure 1 and the summative propositions are presented in Figure 2.

\section{Research implications and limitations}

The model proposed in this paper is exploratory, and the most important research implication is that the proposed model has identified interplay of psychological mechanism of need satisfaction while understanding the relationship between total rewards and retention. Given the multidimensional nature of total rewards, the framework calls for operationalizing a scale to measure the satisfaction of employees with respect to total rewards. This will enable to empirically test the proposed linkages with rest of the variables, viz., mediators and outcome. The authors might like to investigate the collective effect of need satisfaction taken as a composite variable (Baard et al., 2004) along with studying the individual effect of each need satisfaction as carried on by Van den Broeck et al. (2010).
Mediating role of need satisfaction

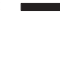


XIMB
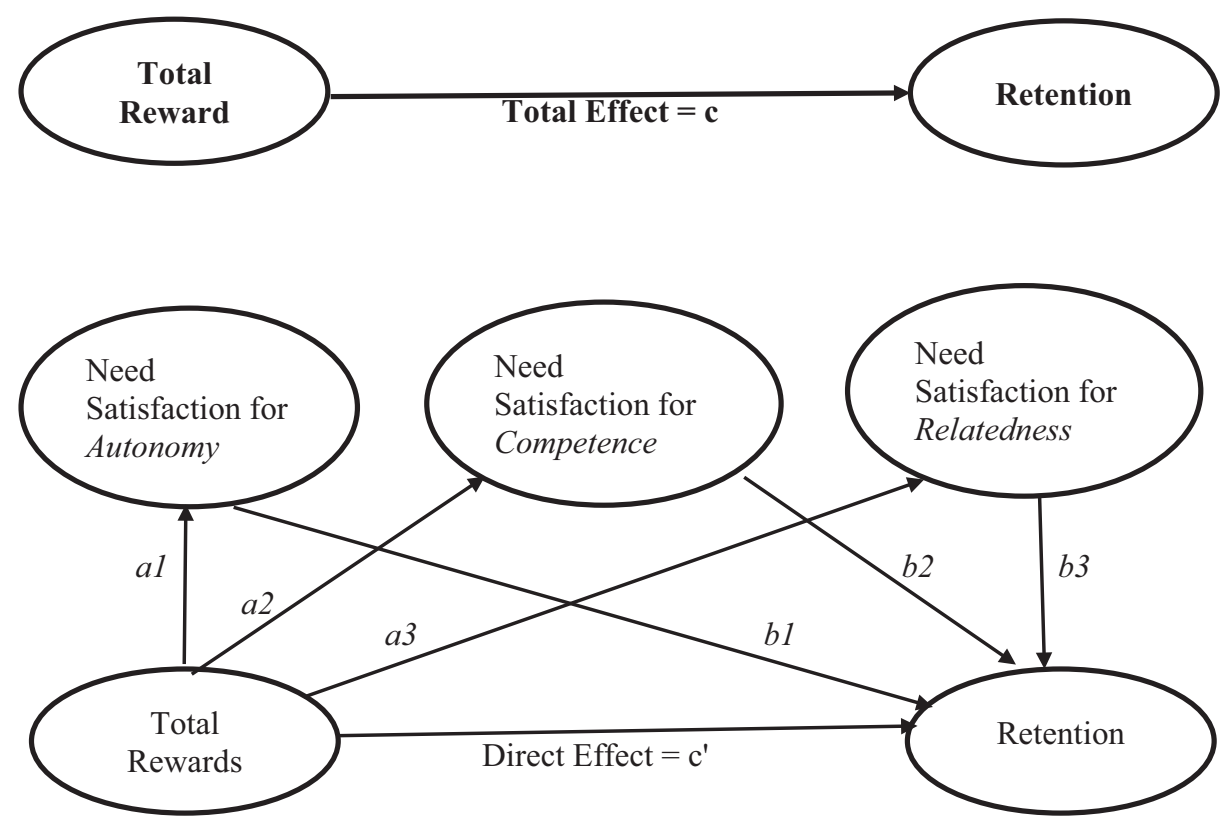

Notes: a1b1: TR->Autonomy->Retention; a2b2: TR->Competence->Retention; a3b3: TR->

Figure 1.

Conceptual model
Relatedness->Retention; c': direct effect of TR on Retention; c: total effect of TR on Retention; $(\mathrm{a} 1 \mathrm{~b} 1) \mathrm{x}(\mathrm{a} 2 \mathrm{~b} 2) \mathrm{x}(\mathrm{a} 3 \mathrm{~b} 3)$ : indirect effect of TR on retention through mediators

Source: Authors' own finding

The four propositions have implications for research in human resource management and organizational psychology. Studies should explicitly consider the interaction between variations in informational and controlling aspect of total rewards and need satisfaction mechanism. More specifically, the study will be more appropriate in explaining variations and its salience in experiencing autonomy, competence and relatedness, thereby affecting the intention to stay. Empirical findings on propositions reflecting interaction between need satisfaction and retention can aid in extending the significance of SDT's assumption of positive outcomes.

The study suffers from unavoidable limitations. Our literature study report failed to discuss other factors, mainly demographic characteristics (e.g. age, gender, qualification and experience) which might play equally significant role in influencing the impact of total rewards and retention. Other moderators such as cultural dimensions and attitude towards money that may give new insights have not been included in our study. In countries with high level of power distance, employees will lead to lower need satisfaction for autonomy and competence (Tepper et al., 2007). Similarly, attitude towards money marked by how employees value money and want to make more money directly influences their retention (Tang et al., 2000). These limitations will offer direction to future researchers in designing their studies by incorporating the moderators excluded in our study. 


\begin{tabular}{|c|c|c|}
\hline Proposition & Path Depiction & Visual Depiction \\
\hline $\begin{array}{l}\text { P1: Total Rewards is } \\
\text { positively associated with } \\
\text { retention }\end{array}$ & $\begin{array}{l}\text { This will be shown by the } \\
\text { direct effect "c"" }\end{array}$ & $\rightarrow$ Retention \\
\hline $\begin{array}{l}\text { P2: Total Rewards is } \\
\text { positively associated need } \\
\text { satisfaction for autonomy, } \\
\text { competence, and relatedness }\end{array}$ & $\begin{array}{l}\text { This will be shown by the } \\
\text { paths a1 for autonomy; a } 2 \\
\text { for competence and a3 for } \\
\text { relatedness }\end{array}$ & $\begin{array}{l}\mathrm{TR} \stackrel{\mathrm{a} 1}{\mathrm{a} 2} \underset{\mathrm{T} 2}{\longrightarrow} \text { Autonomy } \\
\mathrm{TR} \underset{\text { Competence }}{\mathrm{TR} \longrightarrow \text { Relatedness }}\end{array}$ \\
\hline $\begin{array}{l}\text { P3: Need satisfaction for } \\
\text { autonomy, need satisfaction } \\
\text { for competence and need } \\
\text { satisfaction for relatedness is } \\
\text { positively related with } \\
\text { retention }\end{array}$ & $\begin{array}{l}\text { This will be shown by the } \\
\text { paths b1 for autonomy; b2 } \\
\text { for competence and b3 for } \\
\text { relatedness }\end{array}$ & $\begin{array}{l}\text { Autonomy } \underset{\mathrm{b} 2}{\mathrm{~b} 1} \text { Retention } \\
\text { Competence } \stackrel{\mathrm{b} 3}{\longrightarrow} \text { Retention } \\
\text { Relatedness } \mathrm{R} \text { Retention }\end{array}$ \\
\hline $\begin{array}{l}\text { P4: Need satisfaction for } \\
\text { autonomy, need satisfaction } \\
\text { for competence and need } \\
\text { satisfaction for relatedness } \\
\text { mediates the relation between } \\
\text { total rewards with retention }\end{array}$ & $\begin{array}{l}\text { This will be shown by } \\
\text { indirect effect } \\
(\mathrm{a} 1 \mathrm{~b} 1) \mathrm{x}(\mathrm{a} 2 \mathrm{~b} 2) \mathrm{x}(\mathrm{a} 3 \mathrm{~b} 3) \text { and } \\
\text { total effect "c" }\end{array}$ & $\mathrm{c}$ \\
\hline
\end{tabular}

Source: Authors' own finding
Mediating role of need satisfaction

Figure 2.

Summary of propositions and visual depiction

\section{Conclusion}

The research on total rewards and retention spanned from 1990s and still continue to be in demand. Most of the studies chosen for the present study were atheoretical, prescription based and exploratory in nature undertaken by consultants or consulting firms. Analysis of the research on total rewards and retention highlighted unique trends about the theories used. Some supported the central hypotheses with some refuting it. However, most of the research have tried to report positive impact of total rewards on retention via different mediators such as organizational justice, work engagement, commitment, job satisfaction and so on. Further, theory-based studies on total rewards have been mostly empirical focussing on scale development (Twenge et al., 2010; Mabaso and Dlamini, 2021) with very few conceptual studies (Martin and Ottemann, 2016). There has been a steep decline in applying qualitative methods. Our understanding of need satisfaction mechanism influencing rewards-retention relationship will provide new insight into retention literature by focussing on the fact that total rewards is not only about monetary rewards but also inclusive of everything that employees value.

\section{References}

Akhtar, C.S., Aamir, A., Khurshid, M.A., Abro, M.M.Q. and Hussain, J. (2015), "Total rewards and retention: case study of higher education institutions in Pakistan", Procedia-Social and Behavioral Sciences, Vol. 210, pp. 251-259, doi: 10.1016/j.sbspro.2015.11.365.

Alhmoud, A. and Rjoub, H. (2020), "Does generation moderate the effect of total rewards on employee retention? Evidence from Jordan", SAGE Open, Vol. 10 No. 3, pp. 1-15.

Baard, P.P., Deci, E.L. and Ryan, R.M. (2004), "Intrinsic need satisfaction: a motivational basis of performance and well-being in two work settings", Journal of Applied Social Psychology, Vol. 34 No. 10, pp. 2045-2068.

Bharath, M. and Sreedevi, V. (2021), "Zoom in on the levels of employee engagement, perception, satisfaction; employee roles influenced - health care sample study", Vilakshan - XIMB Journal of Management, Vol. 18 No. 1, pp. 62-75. 
Bohlander, G. and Snell, S. (2004), Managing Human Resources, 13th ed., Thomson/South-Western, Mason, $\mathrm{OH}$.

Bryant, P.C. and Allen, D.G. (2013), "Compensation, benefits and employee turnover: HR strategies for retaining top talent", Compensation and Benefits Review, Vol. 45 No. 3, pp. 171-175.

Bussin, M. and Van Rooy, D.J. (2014), "Total rewards strategy for a multi-generational workforce in a financial institution”, SA Journal of Human Resource Management, Vol. 14 No. 1, pp. 11-23.

Cao, Z., Chen, J. and Song, Y. (2013), "Does total rewards reduce the core employees' turnover intention?", International Journal of Business and Management, Vol. 8 No. 20, pp. $62-75$.

Cerasoli, C.P., Nicklin, J.M. and Ford, M.T. (2014), "Intrinsic motivation and extrinsic incentives jointly predict performance: a 40-year meta-analysis", Psychological Bulletin, Vol. 140 No. 4, p. 980, doi: 10.1037/a0035661.

Chiboiwa, M.W., Samuel, M.O. and Chipunza, C. (2010), "An examination of employee retention strategy in a private organisation in Zimbabwe", African Journal of Business Management, Vol. 4 No. 10, pp. 2103-2109.

Close, D. and Martins, N. (2015), "Generational motivation and preference for reward and recognition", Journal of Governance and Regulation, Vol. 4 No. 3, pp. 259-270.

Cropanzano, R. and Mitchell, M.S. (2005), "Social exchange theory: an interdisciplinary review”, Journal of Management, Vol. 31 No. 6, pp. 874-900.

Deci, E.L., Koestner, R. and Ryan, R.M. (2001), "Extrinsic rewards and intrinsic motivation in education: reconsidered once again", Review of Educational Research, Vol. 71 No. 1, pp. 1-27, doi: 10.3102/ 00346543071001001.

Deci, E.L., Koestner, R. and Ryan, R.M. (1999), “A meta-analytic review of experiments examining the effects of extrinsic rewards on intrinsic motivation", Psychological Bulletin, Vol. 125 No. 6, pp. 627-668.

Deci, E.L., Olafsen, A.H. and Ryan, R.M. (2017), "Self-determination theory in work organizations: the state of a science", Annual Review of Organizational Psychology and Organizational Behavior, Vol. 4 No. 1, pp. 19-43.

Deci, E.L. and Ryan, R.M. (2000), "The 'what' and 'why' of goal pursuits: human needs and the selfdetermination of behavior", Psychological Inquiry, Vol. 11 No. 4, pp. 227-268.

De Gieter, S. and Hofmans, J. (2015), "How reward satisfaction affects employees' turnover intentions and performance: an individual differences approach", Human Resource Management Journal, Vol. 25 No. 2, pp. 200-216, doi: 10.1111/1748-8583.12072.

Fobian, D. and Maloa, F. (2020), "Exploration of the reward preferences of generational groups in a fastmoving consumer goods organisation", SA Journal of Human Resource Management, Vol. 18 No. 1, pp. 1-11.

Gagné, M. and Deci, E.L. (2005), "Self-determination theory and work motivation", Journal of Organizational Behavior, Vol. 26 No. 4, pp. 331-362.

Gözükara, İ. and Şimşek, O.F. (2015), "Linking transformational leadership to work engagement and the mediator effect of job autonomy: a study in a Turkish private non-profit university", Procedia - Social and Behavioral Sciences, Vol. 195, pp. 963-971.

Greguras, G. and Diefendorff, J. (2009), "Different fits satisfy different needs: linking personenvironment fit to employee commitment and performance using self-determination theory", Journal of Applied Psychology, Vol. 94 No. 2, pp. 465-477.

Gulyani, G. and Sharma, T. (2018), "Total rewards components and work happiness in new ventures: the mediating role of work engagement", Evidence-Based HRM: a Global Forum for Empirical Scholarship, Vol. 6 No. 3, pp. 255-271.

Haivas, S., Hofmans, J. and Pepermans, R. (2014), "What motivates you doesn't motivate me: individual differences in the needs satisfaction-motivation relationship of Romanian volunteers", Applied Psychology, Vol. 63 No. 2, pp. 326-343. 
Hill, B. and Tande, C. (2006), "Total rewards: the employment value proposition”, Workspan, Vol. 10 No. 6, pp. 19-22.

Huang, Z. and Tianshu, N.I.N.G. (2013), "Impact of total rewards on animation employees' engagement”, Studies in Sociology of Science, Vol. 4 No. 3, pp. 58-64.

Jiang, Z., Xiao, Q., Qi, H. and Xiao, L. (2009), "Total reward strategy: a human resources management strategy going with the trend of the times", International Journal of Business and Management, Vol. 4 No. 11, pp. 177-183.

Lian, H., Ferris, D.L. and Brown, D.J. (2012), "Does taking the good with the bad make things worse? How abusive supervision and leader-member exchange interact to impact need satisfaction and organizational deviance”, Organizational Behavior and Human Decision Processes, Vol. 117 No. 1, pp. 41-52.

Li-Ping Tang, T., Kim, J.K. and Shin-Hsiung Tang, D. (2000), "Does attitude toward money moderate the relationship between intrinsic job satisfaction and voluntary turnover?", Human Relations, Vol. 53 No. 2, pp. 213-245.

Mabaso, C.M. and Dlamini, B.I. (2021), "Investigating the total rewards and its effects on organisational commitment in higher education institutions", Insights into Economics and Management, Vol. 7, pp. 69-82.

Martin, T.N. and Ottemann, R. (2016), "Generational workforce demographic trends and total organizational rewards which might attract and retain different generational employees", Journal of Behavioral and Applied Management, Vol. 16 No. 2, pp. 1160-1171.

Morgan, J.C., Dill, J. and Kalleberg, A.L. (2013), “The quality of healthcare jobs: can intrinsic rewards compensate for low extrinsic rewards?", Work, Employment and Society, Vol. 27 No. 5, pp. 802-822.

Mulvey, P.W., Ledford, Jr, G.E. and LeBlanc, P.V. (2000), "Rewards of work", The Journal of Total Rewards, Vol. 9 No. 3, pp. 6-11.

Nienaber, R., Bussin, M.H.R. and Henn, C. (2011), "The relationship between personality types and reward preferences", Acta Commercii, Vol. 11 No. 2, pp. 56-79.

Peluso, A.M., Innocenti, L. and Pilati, M. (2017), "Pay is not everything: differential effects of monetary and non-monetary rewards on employees' attitudes and behaviours", Evidence-based HRM, Vol. 5 No. 3, pp. 311-327, doi: 10.1108/EBHRM-07-2015-0031.

Prouska, R., Psychogios, A.G. and Rexhepi, Y. (2016), "Rewarding employees in turbulent economies for improved organisational performance: exploring SMEs in the South-Eastern european region", Personnel Review, Vol. 45 No. 6, pp. 1259-1280.

Olafsen, A.H., Halvari, H., Forest, J. and Deci, E.L. (2015), "Show them the money? The role of pay, managerial need support, and justice in a self-determination theory model of intrinsic work motivation", Scandinavian Journal of Psychology, Vol. 56 No. 4, pp. 447-457.

Rai, A., Ghosh, P. and Dutta, T. (2019), "Total rewards to enhance employees' intention to stay: does perception of justice play any role?", Evidence-based HRM, Vol. 7 No. 3, pp. 262-280, doi: 10.1108/ EBHRM-07-2018-0045.

Rathi, N. and Lee, K. (2017), "Role of basic psychological need satisfaction in retaining talent: an investigation in the Indian context", Asia-Pacific Journal of Business Administration, Vol. 9 No. 1, pp. 2-15.

Rosen, C.C., Ferris, D.L., Brown, D.J., Chen, Y. and Yan, M. (2014), "Perceptions of organizational politics: a need satisfaction paradigm”, Organization Science, Vol. 25 No. 4, pp. 1026-1055.

Ryan, R.M. and Deci, E.L. (2017), Self-Determination Theory: Basic Psychological Needs in Motivation, Development, and Wellness, Guilford Publications.

Rybnicek, R., Bergner, S. and Gutschelhofer, A. (2019), "How individual needs influence motivation effects: a neuroscientific study on McClelland's need theory", Review of Managerial Science, Vol. 13, pp. 443-482, doi: 10.1007/s11846-017-0252-1.

\section{Mediating role of need satisfaction}


Schlechter, A., Hung, A. and Bussin, M. (2014), "Understanding talent attraction: the influence of financial rewards elements on perceived job attractiveness", SA Journal of Human Resource Management, Vol. 12 No. 1, pp. 1-13, doi: 10.4102/sajhrm.v12i1.647.

Silverman, M. and Reilly, P.A. (2003), How Flexible is Total Reward?, Institute for Employment Studies, Brighton.

Smit, W.A., Stanz, K.J. and Bussin, M. (2015), "Retention preferences and the relationship between total rewards, perceived organisational support and perceived supervisor support", South African Journal of Human Resource Management, Vol. 13 No. 1, pp. 665-678.

Steindórsdóttir, B.D., Nerstad, C.G. and Magnúsdóttir, K.P. (2020), "What makes employees stay? Mastery climate, psychological need satisfaction and on-the-job embeddedness", Nordic Psychology, Vol. 73 No. 1, pp. 1-25.

Taamneh, A., Alsaad, A.K. and Elrehail, H. (2018), "HRM practices and the multifaceted nature of organization performance: the mediation effect of organizational citizenship behavior", EuroMed Journal of Business, Vol. 13 No. 3, pp. 315-334.

Tepper, B.J., Moss, S.E., Lockhart, D.E. and Carr, J.C. (2007), "Abusive supervision, upward maintenance communication, and subordinates' psychological distress", Academy of Management Journal, Vol. 50 No. 5, pp. 1169-1180.

Thibault Landry, A. and Whillans, A. (2018), "The power of workplace rewards: using selfdetermination theory to understand why reward satisfaction matters for workers around the world", Compensation and Benefits Review, Vol. 50 No. 3, pp. 123-148.

Tiwari, S. and Garg, P. (2019), "Promoting basic need satisfaction at workplace: the relevance of mindfulness in support of job performance of employees", Jindal Journal of Business Research, Vol. 8 No. 1, pp. 1-15.

Twenge, J.M., Campbell, S.M., Hoffman, B.J. and Lance, C.E. (2010), "Generational differences in work values: leisure and extrinsic values increasing, social and intrinsic values decreasing", Journal of Management, Vol. 36 No. 5, pp. 1117-1142.

Van den Broeck, A., Vansteenkiste, M., De Witte, H., Soenens, B. and Lens, W. (2010), "Capturing autonomy, competence, and relatedness at work: construction and initial validation of the workrelated basic need satisfaction scale", Journal of Occupational and Organizational Psychology, Vol. 83 No. 4, pp. 981-1002, doi: 10.1348/096317909X481382.

Vansteenkiste, M. and Deci, E.L. (2003), "Competitively contingent rewards and intrinsic motivation: can losers remain motivated?", Motivation and Emotion, Vol. 27 No. 4, pp. 273-299.

\section{Further reading}

Brigman, N. and Bussin, M.H. (2019), "Evaluation of remuneration preferences of knowledge workers", SA Journal of Human Resource Management, Vol. 17 No. 1, pp. 1-10.

Bussin, M.H., Serumaga-Zake, P. and Mohamed-Padayachee, K. (2019), "A total rewards framework for the attraction of generation Y employees born 1981-2000 in South Africa", SA Journal of Human Resource Management, Vol. 17 No.1, pp. 1-14.

Day, J.W., Holladay, C.L., Johnson, S.K. and Barron, L.G. (2014), “Organizational rewards: considering employee need in allocation”, Personnel Review, Vol. 43 No. 1, pp. 74-95.

Deci, E.L. (2001), "Need satisfaction, motivation, and well-being in the work organizations of a former Eastern bloc country: a cross-cultural study of self-determination", Personality and Social Psychology Bulletin, Vol. 27 No. 8, pp. 930-942.

Ryan, R.M. and Deci, E.L. (2000), "Self-determination theory and the facilitation of intrinsic motivation, social development, and well-being", American Psychologist, Vol. 55 No. 1, pp. 68-78. 
Singh, S., Singh, S.K. and Srivastava, S. (2020), "Relational exploration of the effect of work-related scheme on job satisfaction”, Vilakshan - XIMB Journal of Management, Vol. 17 Nos 1/2, pp. 111-128.

Wang, Y.D., Yang, C. and Wang, K.Y. (2012), “Comparing public and private employees' job satisfaction and turnover", Public Personnel Management, Vol. 41 No. 3, pp. 557-573.

WorldatWork (2010), "The relative influence of total rewards elements on attraction", Motivation and Retention, WorldatWork, Arizona.

Zingheim, P.K., Schuster, J.R. and Dertien, M.G. (2009), "Compensation, reward and retention practices in fast-growth companies”, World at Work Journal, Vol. 18 No. 2, pp. 22-39.

\section{Corresponding author}

Lalatendu Kesari Jena can be contacted at: 1kjena@xim.edu.in

For instructions on how to order reprints of this article, please visit our website:

Mediating role of need satisfaction 